\title{
Development of Interactive Multimedia on The Subject of the Nervous System for Students Grade XI of Senior High School
}

\author{
Siti Nailatul Farkhah ${ }^{1}$, Wachju Subchan ${ }^{1}$, Mochammad Iqbal ${ }^{1}$ \\ Biology Education, Faculty of Teacher Training and Education, University of Jember \\ Kalimantan Street 37, Jember 68121 \\ E-mail: wsubchan@gmail.com
}

\begin{abstract}
This research aimed at determining the validity of interactive multimedia on the nerve system material that had been developed and finding out the students' response to the interactive multimedia. This was a developmental research (Research and Development) followed by a small group test on the eleventh-grade students of SMAN Ambulu totaling 9 students. The students were selected based on their ability level; 3 students with high ability level, 3 students with moderate ability level and 3 students with low ability level. The data collection techniques used were experts' validation sheets and questionnaires. The design of the interactive multimedia in this research was 4D (define, design, develop and disseminate) model developed by Thiagarajan (1974). The developmental procedure of 4D consists of 4 stages: (1) define, (2) design, (3) develop and (4) disseminate. The results showed that the validity of the developed interactive multimedia reached $82.9 \%$ according to the content expert, $86.3 \%$ based on the learning expert, $88,3 \%$ based on the learning media expert, and $82.7 \%$ based on the teacher's (user) perspective. The results of small group test revealed that the legibility and the level of difficulty were $81.99 \%$ or in the good category, and student response score was $83.55 \%$, it means that student had positive response toward the use of developed media in their learning.
\end{abstract}

Keywords: interactive multimedia, 4D, expert validity.

\section{INTRODUCTION}

Entering the 21st century, education is very important for students to learn and innovate, developing their skills by using technology and information media as well as improving the soft skills to face several complex challenges and preparing themselves to be qualified human resources who are able to compete in the globalization era. The learning outcome is an essential matter in education and can be seen as one of the measures of students' success in the school education (Syarifuddin, 2014).

The preliminary study conducted by the researchers on Saturday, $18^{\text {th }}$ March 2017 at SMA Negeri Ambulu, Jember. The researchers interviewed the Biology teacher class XI IPA that Biology learning had some obstacles like the students did not actively participate in the learning process. In addition, based on the interview with both the teacher and students, the method which commonly used was lecture method, discussion, and question and answer.
The learning process used a whiteboard, powerpoint, and practicum media.

The learning innovation can be done by utilizing information technology, for example by using Macromedia flash application as an interactive media. This application provides the materials in the form of animation. Animation is the part of interactive media system which is structured integrally becomes an animated material and video. The interactive media can help the students in understanding the abstract materials and ease the material delivery, gain the students' motivation in learning so that it can improve the students' learning outcomes. The learning media also an important element in the learning process because it contains information and learning messages.

The results of Computer Technology Research (CTR) showed that an individual could only remember what he saw at 20\%,30\% of what he heard, $50 \%$ from what he heard and saw, and $80 \%$ of what he heard, saw, and did simultaneously. This means that the use of

Bioedukasi Vol. XVI. No. 2 Oktober 2018

Received 9 August 2018 | Received in revised form 8 September 2018 | Accepted 22 September 2018 | Published online 1 October 2018 
media like interactive media allows the students to reach $80 \%$ of learning outcomes from what they have learned (Nopriyanti, 2015: 224).

Based on the explanation above, therefore it is necessary to conduct a research about the interactive media development on the nerve system material. The differences between the present study and the previous studies were at the substances of material, research location, object, and subject observed. Thus, the research entitled "An Interactive Multimedia Development on the Nerve System Material for the Eleventh Grade of Senior High School (SMA) Students was conducted.

\section{RESEARCH METHODOLOGY}

This research is a developmental research (research and development). The product developed was an interactive multimedia which is a multimedia-based learning media for the eleventh-grade students of senior high school on the nerve system material. This development referred to the $4 \mathrm{D}$ model (Define, Design, Develop and Disseminate). However, this research was only carried out until the development stage. The further research was carried out the practicality test to see the students' response.

This research used several data collection methods: the validation sheets to measure the validity of the interactive multimedia, while the students' response questionnaire of practicality was given to the students after the readability test in the small group (Small Group Test).

The following were the analysis used during the research, as follows:

a. The Validity of Interactive Multimedia

The validity of interactive multimedia was analyzed by using percentage data analysis technique.

The formulation of data processing for each aspect assessed:

$$
P i=\frac{x i}{y i} X 100 \%
$$

The formulation of the whole data processing:

$$
\mathrm{Pi}=\frac{\sum_{i=0}^{n} x i}{\sum_{i=0}^{n} y i} \times 100 \%
$$

Description:

Pi: percentage of assessment for aspect $\mathrm{i}$

$\mathrm{X}$ : number of assessment answers from the validator for the aspect $\mathrm{i}$

Yi: number of maximum scores for the aspect $i$

P: percentage of the whole score

$\mathrm{N}$ : number of aspects started

i $\quad: 1,2,3, \ldots, \mathrm{n}$ (Suparno, 2011)

Then, the assessment percentage obtained was converted into descriptive quantitative data by using the validity criteria as shown in Table 1.

Table 1. The Criteria of Interactive

\begin{tabular}{|c|c|c|c|}
\hline No & Value & Qualification & Decision \\
\hline 1 & $\begin{array}{l}85 \%- \\
100 \%\end{array}$ & Very valid & $\begin{array}{l}\text { The product was } \\
\text { ready to utilize for } \\
\text { learning activities } \\
\text { without revisions. }\end{array}$ \\
\hline 2 & $\begin{array}{l}75 \%- \\
84 \%\end{array}$ & Valid & $\begin{array}{l}\text { The product was } \\
\text { ready to utilize for } \\
\text { learning activities } \\
\text { without revisions } \\
\text { or allowed to add } \\
\text { something which } \\
\text { was lack. }\end{array}$ \\
\hline 3 & $\begin{array}{l}65 \%- \\
74 \%\end{array}$ & Fairly valid & $\begin{array}{l}\text { The product could } \\
\text { be continued by } \\
\text { adding something, } \\
\text { taking certain } \\
\text { considerations, the } \\
\text { addition was not } \\
\text { too great and basic. }\end{array}$ \\
\hline 4 & $\begin{array}{l}55 \%- \\
64 \%\end{array}$ & Less valid & $\begin{array}{l}\text { Revise and re- } \\
\text { examine to find the } \\
\text { product } \\
\text { weaknesses to be } \\
\text { refined. }\end{array}$ \\
\hline 5 & $\begin{array}{l}0 \%- \\
54 \%\end{array}$ & Not valid & $\begin{array}{l}\text { Revise the content } \\
\text { of the product } \\
\text { greatly. }\end{array}$ \\
\hline
\end{tabular}
Multimedia Validation

b. The Students' Response Questionnaire

The students' response questionnaire was used to measure the students' opinions on the interactive multimedia. The percentage of the students' response for each item was calculated by using the following formula:

Percentage $(\mathrm{Xi})=\sum A \times 100 \%$

$$
\sum B
$$

Bioedukasi Vol. XVI. No. 2 Oktober 2018 
Notes:

$\mathrm{A}=$ number of students who choose

$\mathrm{B}=$ number of students

$\mathrm{Xi}=$ students' response percentage

$100=$ constant number

The percentage of the score results were categorized to determine the high of response on the interactive multimedia teaching material. Table 2. The High Score of the Students'

Response on the Interactive Multimedia Teaching Material

\begin{aligned} & \hline \multicolumn{1}{c}{$\mathrm{C}$} \multicolumn{1}{c}{ Category } \\ & \hline $80 \% \leq X \leq 100 \%$ Very positive \\ & \hline $60 \% \leq X \leq 80 \%$ Positive \\ & \hline $40 \% \leq X \leq 60 \%$ Fair \\ & \hline $20 \% \leq X \leq 40 \%$ Less \\ & \hline$X<40 \%$ Very less positive \\ & \hline\end{aligned}

\section{RESULT AND DISCUSSION}

\section{Research Result}

This is a development research that aimed to obtain interactive multimedia product on the material of the nerve system for the $\mathrm{XI}^{\text {th }}$ grade of Senior High School. According to Arifiyani (2015), the development design uses a 4D (Define, Design, Develop, Disseminate) development model that developed by Thiagarajan. The explanation of the result of the development process in this research is as follows:

\section{a. The defining stage result}

The defining stage aimed to define and determine the learning needs by analyzing the objectives and boundaries of the material which consisted of the analysis from the start to the end, this activity analyzed the curriculum used at SMA Negeri Ambulu. The student analysis based on the results of the questionnaire on both teacher's and students' needs. Besides, the researchers also analyzed the cognitive learning outcomes of students in the previous material.

The concept analysis was that researchers analyzed the main concept in the material of the nerve system so that it became a concept map taught. In addition, the researchers also analyzed the learning resources used to support the process of making interactive multimedia. The learning resources were in the form of books, e-books and supporting images from the internet.

The task analysis refers to the 2013 curriculum syllabus. The task used during the learning process was summarizing the learning results at the end of each lesson and discuss the topic that had been provided. The specification of learning objectives by developing indicators of learning outcomes and objectives achievement based on the standard competence and basic competence.

\section{b. The designing result}

The designing stage consisted of several stages that were the preparation stage of the test for interactive multimedia content, the preparation of quiz which was used as an evaluation tool to measure the completeness of the material, the learning objectives, and the students' understanding level.

In the media selection process, the researchers considered the material used, that was the nerve system. At this stage, the selected media were audiovisual media that were interactive multimedia as a support in the learning process.

In the format selection process, the researchers designed the content of learning, the selection of learning resources and continued with the initial design in the form of a prototype 1 which included home display, basic competence, learning objectives, materials, simulations, quizzes, and bibliography. This stage was carried out to make learning media in accordance with the results framework of curriculum analysis, the student analysis, task analysis, objective specifications, format, and media selection. The product result (prototype 1) was validated for further improvement.

\section{c. The development stage result}

The development stage was in the form of a revised product based on the input from the validators and data obtained from the development test. The interactive multimedia validation was done before the interactive multimedia was used in the classroom for learning activities. The expert validation was carried out by four validators, who were Dr. Jekti Prihatin, M.Si as an expert in material, Prof. Dr. Suratno, M.Si as an expert in teaching materials development, Priza Pandunata S. Kom., M.Sc. as an expert in interactive multimedia Macromedia-flash and Sunanil Huda, S.Pd as a user (teacher). The results of the assessment by the validators on interactive multimedia can be seen in Table 3 . 
Table 3 Analysis of Interactive Multimedia Material Expert Validation

\begin{tabular}{llll}
\hline No & Validator & $\begin{array}{c}\text { Average of } \\
\text { Assessment } \\
\text { Result (\%) }\end{array}$ & Category \\
\hline 1. & $\begin{array}{l}\text { Material } \\
\text { expert }\end{array}$ & 82,9 & Valid \\
\hline 2. & $\begin{array}{l}\text { Expert in the } \\
\text { development } \\
\text { of teaching } \\
\text { material }\end{array}$ & 86,3 & $\begin{array}{l}\text { Very } \\
\text { valid }\end{array}$ \\
\hline 3. & $\begin{array}{l}\text { Media } \\
\text { expert }\end{array}$ & 88,3 & $\begin{array}{l}\text { Very } \\
\text { valid }\end{array}$ \\
\hline 4. & $\begin{array}{l}\text { User } \\
\text { (teacher) }\end{array}$ & 82,7 & valid \\
\hline Average & 85,05 & $\begin{array}{l}\text { Very } \\
\text { valid }\end{array}$ \\
\hline
\end{tabular}

The qualitative data for expert validators in the form of suggestions and comments were used as a reference to revising the interactive multimedia developed.

Table 4 The validators' assessment result of the interactive multimedia based on suggestion and comment

\begin{tabular}{|c|c|c|c|}
\hline No & Validator & $\begin{array}{l}\text { Suggestion } \\
\text { and comment }\end{array}$ & Description \\
\hline 1. & $\begin{array}{l}\text { Material } \\
\text { expert }\end{array}$ & $\begin{array}{l}\text { The } \\
\text { interactive } \\
\text { multimedia } \\
\text { is good, } \\
\text { interesting } \\
\text { and has LDS } \\
\text { with HOTS }\end{array}$ & $\begin{array}{l}\text { The product } \\
\text { is ready to } \\
\text { use in a } \\
\text { learning } \\
\text { activity. }\end{array}$ \\
\hline 2. & $\begin{array}{l}\text { Expert in } \\
\text { the } \\
\text { developm } \\
\text { ent of } \\
\text { teaching } \\
\text { material }\end{array}$ & $\begin{array}{l}\text { The } \\
\text { questions } \\
\text { need } \\
\text { variation and } \\
\text { difficulty } \\
\text { level is even, } \\
\text { to improve } \\
\text { the high } \\
\text { order } \\
\text { thinking } \\
\text { skills of } \\
\text { students }\end{array}$ & $\begin{array}{l}\text { The product } \\
\text { is ready to } \\
\text { use in a } \\
\text { learning } \\
\text { activity; } \\
\text { however, it is } \\
\text { necessary to } \\
\text { revise the } \\
\text { sample } \\
\text { questions so } \\
\text { that the level } \\
\text { of difficulty } \\
\text { varies. }\end{array}$ \\
\hline 3. & $\begin{array}{l}\text { Media } \\
\text { expert }\end{array}$ & $\begin{array}{l}\text {-Very } \\
\text { good } \\
\text {-It will be } \\
\text { better if } \\
\text { the } \\
\text { navigation } \\
\text { between }\end{array}$ & $\begin{array}{l}\text { The product is } \\
\text { ready to use in } \\
\text { a learning } \\
\text { activity, but it } \\
\text { still needs to } \\
\text { improve the } \\
\text { navigation }\end{array}$ \\
\hline
\end{tabular}

the menus between
is
improved,
there are
some
things
related to
the
navigation
between
menus that
still need
to be
fixed.

\section{d. The Small Group Test Result}

Based on table 5 it can be seen that the overall average result of the interactive multimedia validation by the validators was $82.9 \%$ with a very valid category. Then proceed with a small group test that was applied to $9 \mathrm{XI}^{\mathrm{th}}$ grade students of Science from SMA Negeri Ambulu which was based on the students' abilities level, which were 3 students with high ability, 3 students with moderate ability and 3 students with low ability on Friday 24 of November 2017.

Table 5 Small Group Test Data of Interactive

Multimedia in the Material of the Nerve system

\begin{tabular}{llcl}
\hline No & Aspect & $\begin{array}{c}\text { Average } \\
\text { Value (\%) }\end{array}$ & Category \\
\hline 1. & $\begin{array}{l}\text { Readability of } \\
\text { learning media }\end{array}$ & 81,1 & Good \\
\hline $\begin{array}{l}\text { Component of } \\
\text { 2. }\end{array}$ & 84,9 & Good \\
& activities & & \\
\hline & $\begin{array}{l}\text { Readability of } \\
\text { students } \\
\text { activities }\end{array}$ & 80,0 & Good \\
\hline Average & 82,0 & Good \\
\hline
\end{tabular}

e. The Practical Test Result

Practicality test was carried out to obtain students' responses data on interactive multimedia based on questionnaire assessment given to the students. The result of the students' responses analysis can be seen in Table 6 .

Bioedukasi Vol. XVI. No. 2 Oktober 2018 
Table 6 Students' Responses Data on the Interactive Multimedia

\begin{tabular}{|c|c|c|c|}
\hline No & Aspect & $\begin{array}{c}\text { Average } \\
(\%)\end{array}$ & Category \\
\hline \multirow[t]{5}{*}{1.} & Opinion about: & & \\
\hline & a. Learning material & 82,2 & $\begin{array}{l}\text { Very } \\
\text { good }\end{array}$ \\
\hline & b. Learning media & 88,9 & $\begin{array}{l}\text { Very } \\
\text { good }\end{array}$ \\
\hline & c. Student's activity & 75,5 & Good \\
\hline & Average & 82,2 & $\begin{array}{l}\text { Very } \\
\text { good }\end{array}$ \\
\hline \multirow[t]{4}{*}{2.} & Opinion about: & & \\
\hline & a. Language used & 77,8 & Good \\
\hline & b.Presented material & 82,2 & $\begin{array}{l}\text { Very } \\
\text { good }\end{array}$ \\
\hline & Average & 80,0 & Good \\
\hline \multirow[t]{6}{*}{3.} & Opinion about & & \\
\hline & a. Writing & 80,0 & Good \\
\hline & b.Image & 86,7 & $\begin{array}{l}\text { Very } \\
\text { good }\end{array}$ \\
\hline & c. Image layout & 84,4 & $\begin{array}{l}\text { Very } \\
\text { good }\end{array}$ \\
\hline & $\begin{array}{l}\text { d.Stimulation/practic } \\
\mathrm{e}\end{array}$ & 86,7 & $\begin{array}{l}\text { Very } \\
\text { good }\end{array}$ \\
\hline & Average & 84,4 & $\begin{array}{l}\text { Very } \\
\text { good }\end{array}$ \\
\hline
\end{tabular}

4. Macromedia flash-based interactive multimedia is the development of $\quad 86,7$ creative and innovative learning

Very good media

5. What do you think if the next learning activity uses Macromedia flash based 84,4 Very good interactive multimedia

\section{DISCUSSION}

This is a development research. Product in the form of interactive multimedia on the material of nerve system using the 4D model (Define, Design, Develop and Disseminate) consisting of four stages, namely: 1) defining; 2) planning: 3) development and 4) dissemination. However, this research only carried out until the development stage which was then continued with a practicality test.

a. The Defining Stage

The defining stage begins with the initial analysis activity which aims to identify the fundamental problems faced in learning so that a teaching material development is needed
(Mi'rojiyah, 2016). The fundamental problem that needed to be pursued in learning was how to present teaching materials and the implementation of fun learning. At this stage, the researchers reviewed the curriculum that applied for the Senior High School and the curriculum used was the 2013 curriculum.

Students' analysis referred to the questionnaire result on students and teacher needs. Karyanto (2015) states that a questionnaire is a data collection method done by asking written questions to the respondent. Besides, it was used to study students' characteristics like students' cognitive and analysis toward the biology learning on the former lesson and it was found that there were still many students got low score under the minimal score standard. Students' analysis was also obtained from the result of teacher needs questionnaire; it was found that nerve system material was categorized as difficult to be understood because the lesson was an abstract concept, which cannot be seen, about what happened within the human body.

Based on the analysis, the procedure concept that was done was identifying, detailing and arranging the relevant concepts used in the material arrangement. Therefore, by using teaching media, students could learn the nerve system in details and systematically. Mi'rojiyah (2016) states concept analysis needs to be done by conducting basic and standard competences analysis to determine the teaching material, learning source, by collecting and identifying which sources that support the teaching material arrangement.

Task analysis was done based on the nerve system material. Task analysis was adjusted with the basic and standard competencies starting from the material so that the learning objectives could be reached. Based on the standard competence 3.10, it was known that material delivering could be done by implementing various ways like literature study from various source, group discussion, and teaching media usage. Yet, the teaching media used at SMA Negeri Ambulu was limited on printed media like book and module, charts and powerpoint, whereas, the interactive multimedia-based teaching media had never been used.

Based on the specification, the learning objective was determining learning achievement indicator based on the material

Bioedukasi Vol. XVI. No. 2 Oktober 2018 
and curriculum analysis by writing the learning objectives. Therefore, the researcher understood what material needs to be presented through the media, decided the quiz grid through the media and student discussion topic.

\section{b. The Designing Stage (Design)}

Planning stage was intended to prepare the prototype that would be developed. This stage consisted of a test arrangement stage which intended to prepare the measurement tool which used to measure students' initial ability and achievement after the learning process. In this stage, the researcher prepared the quiz draft that would be presented in the interactive multimedia as the students understanding benchmark toward the material.

The chosen media used was interactive multimedia which was considered its appropriateness to the nerve system material, cost, quality, and validity by some experts. The media determination was done to optimize the teaching media usage within students learning process.

Whereas, the format determination was done by deciding and studying some existing teaching media formats such as pictures from the internet, relevant ebook, and the used sound and video. The format determination was done to decide which media was appropriate to present the learning material and interactive multimedia product. The media used in creating the teaching media was Adobe Flash CS6.

In the designing stage, the researcher created an initial product or product design which was the whole activity design that should be done before conducting development stage. The initial product consisted of home display, basic competence, objectives, material, simulation, quiz, and reference. The initial product was intended to give a general overview of the interactive multimedia presentation.

\section{c. The Developing Stage Result (Develop)}

The developing stage was the stage in which a developed product was created through two steps; expert appraisal and developmental testing (Desmiwati, 2017). The aim of developing stage was to create the final product of teaching media after doing revision based on the expert or practitioner suggestion and testing result data.
Validation was a technique to assess the appropriateness of product design. The product validation could be done by the expert or practitioner that had been experienced to assess the weakness and strength of the created product. Interactive multimedia was validated by four validators; material expert, teaching material expert, teaching media expert, and a teacher of SMA Negeri Ambulu. The following were the explanation of the four validators' assessment:

The material validation was done by the nerve system material expert on Friday, November $24^{\text {th }} 2017$, Dr. Jekti Prihatin. This validation prioritized the content of the presented material. The expert assessed the appropriateness of the material listed in the media with basic and standard competencies that should be fulfilled. Based on the validation result, it was known that the developed media reached the average score as much as $82.9 \%$ according to the criteria on conversion table scale 5 , therefore the developed interactive multimedia validity was categorized as good. ${ }^{[4]}$

Interactive multimedia was validated by teaching material expert, Prof. Dr. Suratno, M.Si on Thursday, August $3^{\text {rd }} 2017$ and the validation result got score $86.3 \%$, according to scale 5 conversion, it meant that the developed interactive multimedia was categorized as very valid. Prastowo (2014) states that the functions of learning material for students were: 1) the students could learn without any assistance from teacher or friends; 2) the students could learn everywhere and every time; 3) the students could learn prior to their learning speed; 4) the students could learn according to their own sequence; 5) helping students potency to be independent students; 6) as the guideline for the students who would direct all their activities in learning process and competence substance that should be learned or mastered.

The validation from teaching media perspective was conducted on Thursday, July $27^{\text {th }} 2017$ by Priza Pandunata S.Kom., M.Sc. the teaching media validation, especially on the learning design, could help students to understand the difficult as well as complicated and complex learning material substance. Therefore, the teaching media expert focused on the display or presentation from the teaching media perspective. Arifiyani (2015) stated that the interactive multimedia teaching media characteristics were: 1) having more than one

\section{Bioedukasi Vol. XVI. No. 2 Oktober 2018}


convergent media, like combining audio and visual element; 2) interactive, it meant that it has the ability to accommodate the user response; 3) independent, it meant that it gave easiness and completeness of the content so that the user could use it without any other assistance. Based on those characteristics, it was known that the developed interactive multimedia teaching media reached score $88.3 \%$ according to conversion guideline scale 5 , which meant that from developing teaching material perspective, the developed interactive multimedia was categorized as very valid ${ }^{[4]}$.

The teaching media validation from usage perspective was done by the user (teacher), Sunanil Huda, S.Pd on Friday, November $18^{\text {th }}$ 2017. The validated aspects consisted of material, presentation, and whole function of the teaching media. Based on the obtained data, it was known that the developed teaching media got average score $82.7 \%$ according to the conversion guideline scale 5 , it meant that from the teaching material development, the developed interactive multimedia was categorized as valid ${ }^{[4]}$.

Based on validation result from teaching material experts, material development experts, media experts and teachers (users), it achieved the average scores of $85.0 \%$ in a very-valid category. Hartati (2017) states that although the media has been considered well, it needs to be improved based on the comments and suggestions given by the validators. The results of comments and suggestion given by all validators were used to revise and add several things to learning media. Suggestions and comments given by the validator on interactive multimedia were used to revise the material components as well as the presentation of the developed learning media developed so that the next step could be processed, it was small group test. Based on the comments and suggestions from material experts, interactive multimedia was both good and interesting, it was already supplied by LDS with HOTS (High Order Thinking Skill). In relation to the suggestions and comments suggested by the experts regarding the development of teaching material, the examples of questions needed to be varied and the level of difficulty were evenly distributed to increase the students' high order thinking skill, whereas media experts gave suggestions and comment that the multimedia was very good. However, it would be better if the navigation between menus was improved. The result of media revision related to the development of teaching material was the exercise on interactive multimedia that was revised to be various and its level of difficulty was spread evenly so that it could raise the high order thinking skill of students. The revision which based on the aspect of media was the improvement of navigation in interactive multimedia.

According to Ekawati (2013), finding out the worthiness of learning media can be considered through appropriateness: the material must be suitable to the characteristics of the curriculum applied in school. Accuracy, currency, and clarity: the material is accurate, up to date, clear in explaining the concept, valid and not biased as well as in accordance with the level of difficulty possessed by the students. Screen presentation and design: the screen display uses the combination of colors, images, and coherent and harmonious writing. Text, graphic, color, animation, and audio are needed to assess the screen display. After the media revision, multimedia could be used to small group test.

Small group test was carried out to determine the level of students' readability towards interactive multimedia. According to Mulyatiningsih (2011), limited test aims to anticipate all errors found during the process of development are able to be minimized. In addition, this test collects information which is used as material to improve the products in the upcoming revision. This activity was conducted on 9 natural science students of class XI with different cognitive levels. Small group test was held on $24^{\text {th }}$ of November 2017 in 2017/2018 academic year. This test was done out of the learning hours since it was not included in the learning process in the classroom, the questionnaire was the only one that must be filled by the students.

Small group test was not carried out in the general learning process done by the teacher but in learning media test as it was related to the readability and difficulty level of developed interactive multimedia and the results of the respondents' responses to interactive multimedia. In this implementation, the thing that the researcher developed was interactive multimedia containing material, simulation, and exercise. The developed learning media was shown to make the students enjoy learning

Bioedukasi Vol. XVI. No. 2 Oktober 2018 
in a comfortable and enjoyable atmosphere which lead to an active and effective learning. Therefore, a small group test was done in which it covered the readability and the difficulty of the tests.

Based on small group test, the obtained result concerning on the readability and difficulty of the developed media reached positive results. This was shown by the result of the questionnaire of small group test as a whole obtained the average score of $81.9 \%$. This result indicated that interactive multimedia was developed in a good category.

The next test was the practicality test that gained the result of the respondents' questionnaire analysis in general which showed that the students gave positive responses to the developed interactive multimedia. Multimedia was said to be practical if the device was easy to be implemented.

Based on the respondent's responses questionnaire, it was known that the qualification of the developed learning media was appropriate to be implemented into the real learning.

\section{CONCLUSIONS AND SUGGESTION}

\section{Conclusions}

Based on the result of the analysis and discussion described above, the conclusions are as follows: 1) The result of the validity test of interactive multimedia obtained $82.9 \%$ as its average in a valid category and material validation, the validation of the teaching material development was $86.2 \%$ in the category of very-valid, media validation reached $88.3 \%$ in very-valid category and user validation (teacher) obtained the average validation result of $82.7 \%$ in a valid categories. This shows that the validity level of the developed interactive multimedia can be used for further test in which it is small group test. The result of small group test (Small Group Test) obtained the overall average of each aspect was $81.99 \%$ with a good category. 2) The result of the practicality test was obtained by examining the responses given by the respondents (students) which got $83.55 \%$ as its average result indicating that in general, the students respond positively and interactive multimedia can be used in learning activities. Suggestions

Based on the results of the analysis and discussion, the following suggestions can be summed up as follows: 1) The future researches need to be carried out to the final stage based on 4D development model, which is dissemination stage. So that its influence on the learning process in the classroom can be revealed. 2) For other researchers who are investigating similar researches can develop interactive multimedia on other material by paying attention to the suitability between the material and learning needs.

\section{REFERENCES}

Arifiyani, Rizki., Paseleng, Mila C. 2015. Pengimplementasian pembelajaran Berbasis Multimedia Interaktif pada Mata Pelajaran Matematika di Sekolah Dasar. Scholaria Vol 5, No 2

Arikunto, S. 2009. Prosedur Penelitian Suatu Pendekatan Praktik. Jakarta: Rineka Cipta.

Desmiwati, R., Ratnawulan., Yulkifli. 2017. Validitas LKPD Fisika SMA Menggunakan Model Problem BasedLearning. Jurnal Eksakta Pendidikan (JEP). Volume 1, Nomor 1.

Ekawati,E.Y., Aminah,S., Rofiah, E. 2013. Penyusunan Instrumen Tes Kemampuan Berpikir Tingkat Tinggi Fisika pada Siswa SMP. Jurnal Pendidikan Fisika Vol.1 No.

Hartati, T.W., Lestarari, P.B. 2017. Analisis Pengembangan Bahan Ajar Mikrobiologi Berbasis Inkuiry di IKIP Budi Utomo Malang. BIOEDUKASI, Volume 10, Nomor 2

Karyanto, P., Hastuti, W., Sunarno, W. 2015. Pengembangan Modul IPA Terpadu Berbasis Masalah Dengan Tema Pencemaran Lingkungan. Jurnal Inkuiri, Volume 4, Nomor 3

Mi'rojiyah, Fajar Lailatul. 2016 Pengembangan Modul Berbasis Multirepresentasi pada Pembelajaran Fisika di Sekolah Menengah Atas. ProsedingSemnas Pendidikan IPA Pascasarjana UM Vol.1

Bioedukasi Vol. XVI. No. 2 Oktober 2018 
Mulyatiningsih, Endang. 2011. Metode Penelitian Terapan Bidang Pendidikan. Bandung: CV Alfabeta.

Nopriyanti. 2015. Pengembangan Multimedia Pembelajaran Interaktif Kompetensi Dasar Pemasangan Sistem Penerangan dan Wiring Kelistrikan di SMK. Jurnal Pendidikan Vokasi, Vol 5, Nomor 2

Prastowo, Andi. 2014. Panduan Kreatif Membuat Bahan Ajar Inovatif. Yogyakarta: DIVA Press.

Syarifuddin, H., Helma., Fitri, R. 2014. Penerapan Strategi The FiringLine pada Pembelajaran Matematika Siswa Kelas XI IPS SMA Negeri 1 Batipuh. Jurnal Pendidikan Matematika, Vol.3 No.1

Bioedukasi Vol. XVI. No. 2 Oktober 2018 